\title{
Rule of Law without Secularized Culture is a Myth: A Critical Analysis
}

\author{
Dr. Md Morshedul Islam \\ Professor Department of Law, University of Rajshahi, Bangladesh, Email-p22042012@gmail.com
}

\begin{abstract}
Rule of law is the most uttered and cherished philosophy in present world as it is related to political democracy. ${ }^{1}$ Each democratic or non-democratic regime reiterates her commitment for upholding rule of law in the process of governance. People of the developed and developing countries maintain a simple and honest belief that rule of law is truly practiced in the developed countries- USA, UK, France, etc. But reality is not so. Dicey innovated rule of law principle in 1885, when its total application was absent even in UK. Thereafter 1959 Delhi Declaration incorporated three more principles for making Dicey's rule of law workable. Immediately after Delhi Declaration KC Davis clarified law for making it compatible with rule of law. Rule of law is not workable in a polluted society. Even in a democratic society rule of law is not fruitful if rationality, honesty and sincerity is not found in the action of the government and governed. If ethical values and personality integration are absent in the society rule of law can not achieve its goal. This rationality, honesty, ethical values are nothing but the outcome of secularized culture. Only secularized culture ensures rule of law in the society. State is considered as having secularized character. Secularism denotes to combination of rationality, moral and ethical values, and at last the dictate of right reason of a rational human being. State is emerged to protect and preserve the right to life, liberty and property of the people. But government, the trustee of the state, if not imbibed with this character, rule of law will not be visible in the society. Secularized character of government only expedites the journey of rule of law smooth, free and fruitful and, thereby making democracy and development meaningful. USA, UK and Western European countries are spokespersons of rule of law. Bangladesh and China also propagate rule of law and die for ensuring rule of law. In reality none of these states practice it. The reason lies in the non practice of secularized culture. This paper is intended to find out whether rule of law works without practice of secularized culture or not.
\end{abstract}

Keywords: Rule of Law, Secularized Culture

DOI: $10.7176 / \mathrm{JLPG} / 109-10$

Publication date:May $31^{\text {st }} 2021$

1. Introduction: The government of People's Republic China is very much interested and enthusiastic in bringing about reforms in her judicial system with the object of ensuring rule of law for the common people. ${ }^{2}$ In a totalitarian society like China administering rule of law is not only unthinkable but also ridiculous. Rule of law is the cardinal point of democracy. British political system is based on this principle. AV Dicey innovated this principle in 1885, and 1959 Delhi Conference added three other inevitable conditions for making as well as working of the principle smooth and fruitful. In a rotten society this concept is meaningless without the practice of secular culture by the ruler and ruled. Even in a democratic society this idea faces huge challenge in the absence of secularized culture.

2. Rule of Law after A.V. Dicey: Rule of law is a political concept based on the teaching of A.V. Dicey. Its manifestation is of different types. Implementation of this idea depends upon the political will of the people of concerned system. Its application is visible in a democratic society where secularized culture is nourished and practiced both by the government and governed.

It is said that English Political System is based on rule of law. But till the publication of Dicey's theory in this regard it was not clear what is rule of law. However until the passage of the Act of Ministerial Responsibility 1947 this innovation remained in paper not in practice. Dicey got this theory from the teaching of Chief Justice Cook and he just developed the idea in the following wards.

2.1 Supremacy of law: Dicey indicated the supremacy of ordinary law or in other words in English environment supremacy of common law. Since British Constitution is an unwritten one there is no distinction between ordinary law and constitutional law. The British legislature acts as constituent assembly and legislative assembly as well simultaneously. To him every deed of the government and the government should be carried

\footnotetext{
${ }^{1}$ Shils Edward, Political Development in the New States, Mouton \& Co., The Hague-Paris, 1966 pp.51-62
}

${ }^{2}$ BBC(English)News, October 23, 2014 
out under the law existing at the time of discharge of those duties and responsibilities. It is evident that by sticking to only law, nothing else Dicey basically denounced the presence of discretionary power. However, one important thing he failed to mention regarding the nature of law i.e., what should be the feature of law Dicey advocated for. It is not obvious that he propounded for the supremacy of black law or ill law.

\subsection{Equality before law:}

After Dicey, all are equal in the eye of law whatever may be his/her rank/position in the society. Here he advocated for equal treatment on the basis of required qualification. Perhaps uniform and single set of judicial system was recommended for the application of this equality. That means Dicey expounded against the existence of dual or tripartite sets of judiciary- ordinary court and special court, or ordinary court, tribunal and military court.

\subsection{Predominance of judicial decision:}

Rights and interests of the people shall not be jeopardized without the interference of court i.e., without court order none should be deprived of his rights. Dicey by this principle speaks for judicial supremacy practiced in UK. In English society right to live, liberty, and property are all common law rights which are ensured and protected by the courts through their decisions individually on the basis of merit of each case. However these are fundamental rights in rest of the world. Constitutional court is established for preserving and protecting individual rights against the whims and caprices, and brutality of government. Dicey perhaps is for supremacy of judiciary i.e., what judiciary says that is constitution, not what the legislature passes/ makes. Perhaps he is in favour of primacy of judiciary over other organs. But in England it is not possible because of parliamentary system of government. However in reality practice does not match with the theory in this regard.

\subsection{Shortcomings of Dicey's Concept:}

Explanation of the concept rule of law by AV. Dicey in 1885, according to some, was thought to be the outcome of British political system. Its application was inconsistent even in Dicey's era. However his writing created enthusiastic approach not only among English people and people of British Empire but also among the democracy loving people all over the world regarding what was the approach of their governance and what would it be if total materialization of the idea happens. This effected not only in the marginalization of discretionary power of executive but also holding government liable for wrong doing to its subjects in British political culture. Dicey's innovation finds its footing inoperative elsewhere in the world where English style political culture has not been developed. The advocates for the rule of law theory felt the lacking of some cardinal elements whose existence is inevitably required prior to the working of Dicey's innovation. After years of thinking, debate and discussion the lawyers, judges and professors came to a consensus that rule of law can only be visible if following elements are ensured in a political society and those elements are proclaimed as the prerequisites of rule of law after Delhi Declaration, 1959.

2.4.1 Ensure the enjoyment and protection of certain rights and freedoms by individuals: In English political culture these rights and freedoms are known as common law rights and freedoms. English polity not only provides her citizens with these rights but also employs mechanism for their redress in case of violation thereof. In the context of written constitution like USA these rights are termed as fundamental rights and in modern terms it falls within the ambit of civil liberty. US political culture is very much aware of the full enjoyment of these rights and liberties by the individuals and, state developed techniques in case of their breach. In the context of other countries got independence after $2^{\text {nd }}$ world war from colonial powers though their constitutions put these rights and liberties in pages but in case of application the people got themselves deserted of that.

\subsubsection{Independent judiciary and enriched bar for the protection of fundamental rights:}

Existence of judicial independence is a must for the operation of rule of law. Mere independence in theory but not in practice does not create any environment for nourishment of the same. Whether judiciary enjoys independence or not that depends upon the recognition of the common masses that have practical experience of judicial dealings. Only having of a people oriented free and enriched law practitioners who are satisfied with the smooth working of judiciary may be the evident of rule of law. However the working of a sound as well as enriched bar that advocate for the government is not a sign of rule of law.

2.4.3 Establishment of social, economic and cultural conditions for allowing men to live in dignity and to fulfill their legitimate aspirations: Only people oriented political system where government guarantees normal death to its citizens and people express their views freely without interference of any body including the government can provide such type of atmosphere. Such environment is available only in a secularized political 
democracy. Only a hand pick of nation states in this modern era provide such condition where people live with dignity, and get their aspirations materialized.

The jurists attended Delhi Conference, 1959 framed these new principles of rule of law very cautiously and carefully. They emphasized on enjoyment of fundamental rights, existence of independent and rich judiciary, and economic, social and cultural development for meeting people's basic needs, and at the same time their living in with dignity and getting their desires realized.

Only securing these three conditions could not provide subjects with an honorable and wish fulfilling life in a polity without political freedom.

Keneeth Culp Davis, modern propounder of rule of law termed supremacy of law as rule of law. It is not conceivable how could one element of Dicey's principles uphold modern precept of the same i.e., supremacy of law. However in clarifying the concept Davis emphasized on seven aspects of the theory. These seven aspects ${ }^{1}$ that Davis attributed for melting his precept are basically spoken of praising a complete rational law. In the field of clarifying law (rule of law) all jurists are hiking behind Thomas Acquinas. ${ }^{2}$

The theme that the writing of Dicey carries with and the commitment as well as slogan made on Delhi Declaration are not realistic without political development. Only political development without nourishment of secularized political culture would not be enough for the establishment of rule of law in the society as well as statehood.

3. Secularized Political Culture: Secularism refers to morality, rationality, impartiality of any one be he/she a government officer or common people in his/her action, behaviour and policy. Moral values and rationality is the guide of human actions and policies. Very often secularism is related to religion. Universally accepted rules, norms and values of ethics and morality is the basis of all actions of the government. ${ }^{3}$ Usually secularism is identified with neutrality. Secularism has subtle relation with religion because in all religions, stress is laid upon the nourishment and practice of moral values for the positive progress of the society. However, in running state affairs secularized outlook, actions and behaviour are inevitable for making democracy meaningful. Perhaps for this reason Almond said that unless and until there is a secularized culture in a society, no political development is possible. Democracy is a multi-faceted idea. Only in political democracy civilian supremacy conducted by the elected representative (elected by a free, fair and neutral election) and existence of public liberty are at work. ${ }^{4}$ In fact secularization means rationality (rationalism means- neutrality, impartiality and dictate of right reason). Under secularized environment achievement values are preferred over ascriptive values. The incumbents of any office are legally expected not to exercise their personal will in their official role. In some cases if the law is black the incumbents are expected to be guided by their reasoned judgment. Mutual trust among the politicians is one of the criteria of secularized political culture. ${ }^{5}$ Personality integration is a requisite element of secularized political culture. Political leaders fulfill their pledges made to the people before or after or at any time. Government officers and common people must accomplish the promises made to any person at any moment. ${ }^{6}$ Of all democratic values honesty, sincerity and dedication are cardinal elements for democratic success. ${ }^{7}$ If majority members of the society are not accustomed to secularised political culture rule of law will remain only in theory not in practice. Secularism is nothing but a process of learning. It has to come from the beneath (family). It will not be imposed from above (government). In exercise of power the officials will not bow its head to anybody except the law by which he is guided. And not be dictated by any body else. Law must be the reflection of positive will of the society. Bureaucracy is a rational legal institution. The incumbent of any office is not allowed to use office furniture, office, fund etc for personal use. His official position will not be used in dealing with public. ${ }^{8}$ That is why bureaucracy is termed as rational legal institution.

\footnotetext{
${ }^{1}$ According to rule of law refers to (i)law and order, (ii) fixed rules, (iii) elimination of discretion, (iv) due process of law or fairness, (v) natural law, (vi) preference for judges and (vii) judicial review.

2. After Acquinas a law must contain four features. Those features are-(i) dictate of reason, (ii) for common good, (iii) support of the people, and (iv) legitimacy of the law maker.

${ }^{3}$ MacIver R.M., The Web of Government, Macmillan Company, New York, 1961, pp.73-81, See also Pye Lucian W. \& Verba Sidney, Political Culture and Political Development (Edited), Princeton University Press, New Jersey, 1965, pp.3-26, 133

${ }^{4}$ Shils Edward, Political Development in the New States, Mouton \& Co., The Hague-Paris, 1966, pp.51-52, 47-84

${ }^{5}$ Almond Gabriel A.\& Jr. G. Bingham Powell, Comparative Politics A Developmental Approach, Little Brown \& Company, Boston, USA, 1966, pp.43-63

${ }^{6}$ Ibid

${ }^{7}$ Jennings Sir Ivor, Cabinet Government, Cambridge University Press, UK, 1969, pp.13-19

8 Macridis C. Roy \&Brown E. Bernard, Comparative Politics Notes and Readings (edited), The Dorsey Press, Homewood, Illinois, 1964, pp.415-423.
} 
If the above conditions are available in the society rule of law can be enjoyed. Only existence of structural institution does not guarantee the existence of secularized political culture (rule of law).

\section{Present Condition of Secularized Political Culture in UK:}

United Kingdom is the motherland of the concept of rule of law. All the three prerequisites of rule of law declared in Delhi Declaration are available in Britain. But some recent events give birth to some questions with regard to the practice of rule of law. In 2014 news revealed that some big fishes of British politics who were members of parliament did not pay off their telephone bill, they overdrew extra bill in the name of renovation of their government resident but used the same for personal use, and in some cases they turned official furniture into personal property. The speaker did not take any action against them nor asked them to realize their duties. Even law enforcing authority and income tax authority did ignore these wrong doings. If these misdeeds were committed by common people or government officials they would have been made subject to multiple corruption and criminal proceedings. In English political culture when any allegation is surfaced against any political leader whether from the treasury bench or opposition he/she resigns from their post for the urge of conscience. But in this case no member of parliament either from the treasury bench and opposition resigned. It is too violation of secularized political culture.

Liberal Democratic Party in her election manifesto pledged that tuition fee for higher education (fair taxes i.e., that put money back in pocket) would not be increased. ${ }^{1}$ Liberal Democratic Party formed coalition government with Conservative Party under the leadership of David Cameron in May, 2010. In the same year government doubled tuition fee for higher education. Against the decision of the government London faced huge popular protest and the demonstrator voted for the Liberal Democrat demanded for the immediate resignation of their MPs for deceiving the people. ${ }^{2}$ This u-turn is totally inconsistence with English political culture. People are to obey law but in a secularized society such type of government should not have any moral basis to stay in power for violating election manifesto. That means parliament has no authority to make any law going beyond the words of her election promises even in the name of national interest. If such events occur that is not just and appreciable in the society. The reason and ethical value do never teach dishonesty, deceiving and breach of trust. Thus lack of secularized culture denounces the existence of rule of law in the society.

\section{Condition of Secularized Political Culture in USA:}

America is considered as a place where government and governed are habituated with the principles of rule of law. But sense for rule of law is stronger than that of temporary executive and judges. In spite of adherence of people to rule of law the government, and judiciary are seen not to comply with it because of shortcoming in the practice of secularized culture.

Detention centre as well as prison in present time set up on Cuban soil and carried on by US military from 2002, naked and horrible abuse of detainees without trial by Bush Administrative not only diminished America's image as the upholder of rule of law and free society but also questioned the supremacy of US Constitution. Democratic Party under the leadership of Barak Obama came into power in 2008 with the aim of bringing change in US policy and in its election manifesto it pledged to shut down the Guantanabay detention centre. It did not close the centre in its first tenure. Obama spends second term in office but till 2015 his government has not materialized the election promise. It continues to operate the Guantanamo Bay Detention center. ${ }^{3}$ According to the secularized culture Obama should not stay in power because of not keeping its pledges made before the people in election. Under such atmosphere a sensible human being at least seeks pardon and feels sorry for failure. Democrat government did not admit her inability let alone repent for inaction. This is not rule of law let alone what secularized culture teaches us.

The character of state is nothing but a secular one. It must not behave in bias or irrational means. Its personality is as that of a rational human being free from human enmity and hatred. Secularized culture expects from the government i.e., trustee of the people to act rationally with all friend and foe equally based on reason. In spite of

\footnotetext{
${ }^{1}$ See the Liberal Democrat Manifesto 2010

${ }^{2}$ The guardian, Wednesday, November 10, 2010
}

${ }^{3}$ U.S. Senator John McCain, Senator Kelly Ayotte, Senator Richard Burr and Senator Lindsey Graham hold a news conference to talk about new legislation to restrict prisoner transfers from the detention center at Guantanamo Bay, at the U.S. Capitol in Washington January 13, 2015. 
being advocate of political democracy no US government is seen to uphold spirit of secularism for the mankind particularly towards Palestine. US government supports the Israel blindly. Here the mankind is shattered. Secular character of US as state does not justify this act of her representative character. Even the US Constitution does not authorize the representative of the state USA to stand for killer of humanity. Very recently a group of US Senators threatened to stop financial aid amounting to 400 million US Dollar per year to Palestinian people if Palestinian authority lodges criminal charge against Israel for committing massacre during Gaza War in 2014 in the International Court of Criminal Justice. This is truly violation of secular teaching by US legislators. ${ }^{1}$ Though US Constitution authorizes the government to play the role of protector of human rights and free society yet her trustee ignores it which is not rule of law let alone the rational feature of USA as a state.

US Constitution advocates for the establishment and practice of democratic form of government. Since in mainland USA democratic form of government is at work it is presumed that it injects the same else where in the world no doubt. In Atlantic Charter America, as one of the signatories, promised that democratic government and rule of law would be injected in other countries where USA provides financial aid and assistance. One important thing is that American Constitution empowers the government to take every step and measure for protecting her interest in the world. Secularism must not support nor teaches any interest which is achieved or gained in sacrifice of moral or ethical values. Governments in USA did or do not support democratic government in Latin America, Asia, Africa, European countries. When the people of those countries sacrifice and give blood for that cause US governments ignored and ignore their voice and directly supported and support the authoritarian rule. In the recent history in Egypt Muslim Brotherhood came into power under a free, fair and neutral election. USA supported and supports military coup and overthrow of democratically elected government there. ${ }^{2}$ Not only that encouraged and praised brutal military rule in Algeria in lieu of supporting the democratically elected political party Islamic Salvation Front (FIS) there. ${ }^{3}$ In Saudi Arab there is a dictatorial rule. People there are for greater political liberty. But US government did and does not stand for the people there. ${ }^{4}$ US governments always patronise those regimes that are beneficial for her. But US as a state bears a secular ideology devoid of political or financial goals. Then why the trustees do not imbibe secularized character in them for the up lift of moral and ethical values. This is surely violation of US Constitution ${ }^{5}$ or rule of law which secularized culture does not approve nor teach.

\section{Rule of law in China}

China is a strong economic power in present world. It dominates the political philosophy of third world countries. Some governments of democracy oriented countries like ours in the disguise of perpetuating state power are whispering to introduce so-called China Style democracy in their countries. That's why outlook of China regarding rule of law has been surfaced here.

Socialist political environment exists in People's Republic of China. Being a totalitarian society opposition voice is not tolerated and considered as the enemy of the society and state. None should expect the practice of rule of law in this style of political system. Right to life, liberty, and property the three cardinal elements of statehood is not recognized in this polity. However Chinese polity practices and recognizes state ownership over the property. Right to life and liberty is not recognized. Right to life is not observed in dissident voice. Liberty is not practiced, recognized and honoured in China. State China holds the character of a rational human being. A state should not make difference between her subjects. Being the trustee chinese government does not uphold the personality of rational being which obviously denounces the teaching of secularized culture.

Dictatorship of proletariat is established and practiced in China. This proletariat is composed of peasants and workers class. At the top there is a chairman. Under the socialist practice the means of production and distribution thereof shall be controlled by the state and it shall be distributed to the people according to the requirement of the individual and family members. It is not conceivable why beggars are seen begging in Shanghi streets. On the other hand family members of Party Chairman lead and enjoy luxurious life. According to recent report $90 \%$ China's super rich want to send their children abroad particularly to USA, UK, Germany. ${ }^{6}$ These children use BMW, Maseratis and other high-end autos as their personal transport. Their luxurious life-

\footnotetext{
${ }^{1}$ Reuters, UK Edition, Monday, 19 January, 2015

${ }^{2}$ The Daily Star, 4 July, 2013

${ }^{3}$ Entelis, John P., Democracy Denied: America's Authoritarian Approach Towards the Maghreb - Causes \& Consequences, XVIIIth World Congress of the International Political Science Association, Quebec, 1-5 August 2000.

${ }^{4} 5$ dictators the U.S. still supports". The Week. Retrieved 2014-08-10

${ }_{5}$ DeConde, Alexander et al., ed. (2001). "Dictatorships". Encyclopedia of American Foreign Policy, Volume 1. Simon \& Schuster. p. 499. ISBN 9780684806570.

${ }^{6}$ International Business Times, Friday, February 6, 2015
} 
style is a mere dream for the peasants and beggars begging in the streets of Shanghi and Beijing. ${ }^{1}$ This is not what socialism teaches and for which China adopted socialist economy. It is not rational and just. The practice of dual economic life styles by lower class and upper class of China exhibit the hollowness, mockery and practice of unethical value in the government level. This is not rule of law, let alone secularized culture of which Chinese polity and father of China's communist revolution thought.

Hong Kong returned back to China from UK after the end of 99 years lease. UK set up English political and economic systems in Hong Kong. Under Sino-British Joint Declaration of 1984 it was transferred to China in 1997. China agreed to continue British type democratic rule in Hong Kong. On September 22, 2014 it denied to continue the democratic rule agreed upon with UK in Hong Kong. This is irrational and blatant violation of SinaBritish Joint Declaration. This definitely questions the honesty and sincerity of China leadership. One China two systems Principal is negated here and thus secularized culture is certainly absent in the governance of China. ${ }^{2}$

\section{Secularised Political Culture in Bangladesh:}

Bangladesh was born for the establishment and realization of democracy. Initially she introduced westministerial political system. Within a short span of time the founding father of Bangladesh Bangabandhu Sheikh Mujibur Rahman himself buried the democracy by fourth constitutional amendment by introducing one party authoritarian system of government. ${ }^{3}$ Military ruler Major Ziaur Rahman exhumed the buried democracy by establishing people's supremacy in May, $1977 .{ }^{4}$ With the assassination of President Ziaur Rahman Bangladesh was again dragged into autocratic rule. Second phase of so-called democracy began her journey from 1991. Living in the year 2015 Bangladesh once again is standing on the balance of embracing autocratic rule. In spite of lying on the dead body of democracy the government in power asserts for the practice and exploration of rule of law, and consolidation of democratic rule in Bangladesh. ${ }^{5}$ Before making any comment on the existence of rule of law and democratic government in Bangladesh light should be focused on certain aspects of rule of law and their operation in Bangladesh.

Since Bangladesh is a third world country Dicey's rule of law theory is impracticable without prior implementation of the principles of 1959 Delhi Declaration. According to the requirement Bangladesh Constitution contains a list of fundamental rights for all the people living within its boundary. But these rights are not for the common people let alone the opposition political parties or groups or individuals. It is only for the members of the ruling party and her die-hard followers. Machineries of the government are used not to create environment for the free and unfettered enjoyment of fundamental rights but to curb that. Government machineries protect and encourage the supporters of the ruling party to create bottlenecks to and violate the rights of others freely.

Bangladesh possesses a judiciary and a bar of eminent lawyers and barristers. The highest judiciary which is considered to be the guardian of the constitution and society, safeguard of fundamental rights of the people, is basically the spokesperson of and decriminalization organ of the government. ${ }^{6}$ After 2007 the judiciary has been basically upholding and justifying all unconstitutional, illegal and political agenda of the ruling elite and party. Because of inaction of the judiciary fundamental rights of the people are not only snatched away and brutally destroyed but also vanished off for the dissenting voice in Bangladesh.

The legal professionals and practitioners are divided into two- one is pro-government and another pro-people. The pro-government faction does not see any wrong doing, unconstitutionality, caprice, illegality, or irrationality in the working of the government. These lawyers do never speak for the common masses. Another section of the bar standing by the masses and opposition is not allowed to carry out their professional duty.

Lower judiciary is also directly controlled and forced to materialize the dictation of the authority though government reiterates that mass people, lawyers, and members of judiciary are enjoying the fruits of independent judiciary.

\footnotetext{
${ }^{1}$ Melissa Anders 1 manders@ mlive.com Fellow on Twitter- On April 21, 2014.

${ }^{2}$ BBC News, September 22, 2014

${ }^{3}$ The Fourth Constitutional (Amendment) Act, 1975

${ }^{4}$ The Ittefaq, June 1, 1977, See also the Bangladesh Observer, June 1, 1077

${ }^{5}$ The Janakantho, , August 16, 2015, See also the Bangladesh Pratidin, , August 16, 2015, See also the Ajker Kagoj, August 16,2015

${ }^{6}$ Dr. Jaforullah, the founder of Gono Shastho, Contempt of Court case. The Daily Star, August 31, 2015, See also the Janakantho Contempt of Court Case, the Prothom Alo, August 11, 2015
} 
It is the responsibility of the government to create social, economic and cultural atmosphere for providing people with a life with dignity and fulfilling the desires of the people i.e., government must make congenial environment where people must have the job opportunity and employment in other words economic stability. Society will run on the basis of ethics and moral values. Respect for opposition voice and openness in the actions of the government should exist there. In Bangladesh government promises for creating new jobs and eradicating corruption, in reality it is not seen. However jobs available are given on the basis of political affiliation of the candidates. After 2008 it is found that candidates holding opinion other than government view are disqualified for government jobs in spite of having better qualification and better performance in competitive examination. Government jobs are kept reserved for the supporter of ruling party. In this case qualification and efficiency are not required. ' 'Sit for the BCS, we will take care of' the rest,' HT Imam, PM's political adviser, assured the activists of Chhatra League while addressing them at a function on November 12, 2014. ${ }^{2}$

Ethical and moral values are considered as the enemy of the government. Honesty, sincerity, dedication, and heard working are treated as disqualification if it goes against the policy and decision of the government. Only government recognized groups and individuals enjoy social benefits.

Democracy is a system where people live with dignity and, legitimate rights and desires are available. Unfortunately the features of democracy- freedom of speech, political rights, fundamental rights, transparency and legitimacy of the government and accountability of the government are not existed in Bangladesh. Government machineries distribute state privileges to the yes men of the ruling elite.

Government's first and utmost duty is to ensure normal death to each and every citizen of the country. Law enforcing agencies are considered as savior and protector of normal death. In Bangladesh killing of innocent people in the hands of law enforcing agencies is a normal matter. Law enforcing agencies and government justify these killings in the name of crossfire. From January 5, 2015 to February 26, 2015 fifty opposition political party men and twenty six neutral persons were killed in the hands of RAB and Police as well as ruling party men in the name of crossfire. ${ }^{3}$ These are basically coolheaded murder. Bangladesh Prime Minister Sheikh Hasina and other members of her government ordered the law enforcing agencies to kill political opposition to quell the movement for restoration of democracy against her government. ${ }^{4}$

Legitimacy of the government is a must for running the administration in democratic system. Government gets this legitimacy from the people through a free, fair, neutral and peaceful election accepted by the people concerned. Where legitimacy is absent there remains no accountability of the government. Bangabandhu Sheikh Mujibur Rahman took over the office of President by fourth constitutional change on January 25, 1975 without seeking approval of the people. Since his government had no legitimacy removal of his government by coup was appreciated by the people of that time warmly. ${ }^{5}$ Post coup governments of Khandaker Mushtak Ahmed, Abu Sadat Mohammad Sayeem, and Zia were welcomed with great enthusiasm and appreciation.

General Ershad took over state power ousting democratically elected legitimate government on March 24, 1982. Ershad was in power for eight years but he had no legitimacy because elections under his auspices were farce and not accepted by the people. Thus his removal was joyful to the people. ${ }^{6}$

The $15^{\text {th }}$ February, 1996 election was not free, fair and genuine one. People's participation was not there. ${ }^{7}$ The government formed on the basis of that election result lacked of legitimacy. That's why Begum Khaleda Zia's second termed government had to resign within a short span for allowing the people to express their voice in a free, fair, neutral and peaceful election on June $12,1996 .^{8}$

On $5^{\text {th }}$ January, 2014 general election one hundred and fifty four Members of Parliament out of three hundred were made legislators without election. In rest of the seats where election was held voter turn-out there was

\footnotetext{
1 The New Age, November 13, 2014.

${ }^{2}$ Ibid

${ }^{3}$ The Naya Diganta, February 27, 2015

${ }^{4}$ BTV News, January 28, 2015, Bd News.com, January 28, 2015, The Daily Star, January 29,2015, The Prothom Alo, January 29,2015

${ }^{5}$ The Morning News, August 20, 1975, The Bangladesh Observer, August 21, 1975

${ }^{6}$ The Daily Star, December 7, 1990

${ }^{7}$ The New Nation, February 13, 1996.

${ }^{8}$ The Independent, June 14, 1996
} 
actually less than one percent. ${ }^{1}$ The people rejected the election and tenth parliament has no legitimacy to run the government. But the highest court upheld the election of tenth parliament as a legitimate one ignoring the voice of the people as well as norms and values of democracy. ${ }^{2}$ Since there is lack of legitimacy the current government has accountability to none. The farce is that government asserts and claims her as a democratic government. Current government turns down any question of legitimacy and terms every attempt in this regard as treason and brands the voice as enemy of the state, society and independence of the state. This is the sign of autocratic system in which rule of law has no place.

Democratic government means government by the consent of the governed. ${ }^{3}$ Media-electronic and print plays very significant role in creating and mobilizing public opinion (consent) in the society. In democracy where effective opposition is not available or where no opposition is present media not only creates and mobilizes public consent but also assumes the role of watch dog on the actions of the government as like as opposition. In Bangladesh current government is very much pro-active in curbing the democratic role of media. Not only that, it blocks all those media which explore the positive opinion of the society. It endeavors to create her positive image through this media. People as a whole are reluctant to digest the negative attempt of the media in this regard. Government stopped publication and circulation of several print media such as the Amar Desh, the Inqilab, and imposed ban on broadcasting news channels viz., Diganta TV, Peace TV. With the object of showing positive side of present government it drastically censored every news and views before reaching to common masses. Thus media as an active opposition is not available right now in Bangladesh. Rule of law does not support and advocate this type of media that stands by and upholds government decision and policy as the consent of the society.

Rule of law is the core and vital element of democracy. Democracy without political right is worthless. Meeting, conference, procession, public gathering, protest, human chain etc are the means of expressing political right. These means are enjoyed by the ruling party and its affiliated political parties. Opposition parties and other groups are not allowed to practice these within Dhaka. And elsewhere in the country, these are drastically curtailed by using law enforcing agencies and party men in the name of keeping law and order. Democracy without political right is autocracy and rule of law is unthinkable there.

\section{Comment and Suggestions}

Nowadays in the name of free society and rule of law political leaders in developed and under developing countries depict non observation of religion in their actions in materializing the concept of secularism. Even the western news medias viz., CNN, BBC and AL-JAZEERA condemn and question the secular status of state and government when any self-declared atheist is attacked for preaching dirty, abusive, defamatory, ugly statement and comment against religion and practicing unethical lifestyle. ${ }^{4}$ Ignoring religion in the actions of government is branded as the sign of secularism in modern world. However the modern world some time is fumbled when something reverse is seen in their actions and policies. In UK the British Crown is restricted to the king/queen who holds protestant faith in case of religion. In English culture such type of religious belief and practice defies their concept of secularism, no doubt. Democracy and rule of law do not uphold and support this dual role.

In USA President George W. Bush on October 7, 2001 before the start of military mission known war against terror in Afganistan arranged a meeting of Christian religious leaders of US Churches at White House. President W. Bush sought their blessing and cooperation for the successful military mission in Afgan war. ${ }^{5}$ It is not clear why President negated his secular position by arranging religious prayer in his official Palace in spite of being the spokesperson of secularism. It might have been a mistake or dual face of western political figure. It is against secularized culture.

Professor Salman Rushdie drew the attention of world community after publishing the novel 'the Satanic Verses' in 1988. In this book he terms the holy Quran as the verses of devil, and defamed Prophet (sm), Muslim and

\footnotetext{
${ }^{1}$ The Rtv News, The Banglavision TV News, The ETV News, The Channel 24 News, January 5, 2014

${ }^{2}$ The Daily Star, June 20, 2014. See also bdnews24.com, August 14, 2015

${ }^{3}$ Jennings Sir Ivor, Cabinet Government, Cambridge University Press, UK, 1969, pp.13-19
}

\footnotetext{
${ }^{4}$ Reporters affiliated to BBC, CNN, AL-JAZEERA termed Abhijit Roy who was stabbed to death at Ekushe Book fair on February 22, 2015 as the pioneer of secularized thought and culture in Bangladesh. They reported that the killing of Abhijit is a great loss for development and progress of secular political culture in Bangladesh. In reality he was a self-declared atheist and practice abnormal lifestyle subversive to Bangladesh values and culture. Not only that he operated a blog "Muktomona" which criticized religion, god fearing people, and sound moral norms and values practiced by Bangladeshi.

${ }^{5}$ BBC News, at 8 pm, October 6, 2001
} 
Islam using abusive words. The book received 1988 Booker Prize. Ayatollah Ruhollah Khomeni the Supreme leader of Iran pronounced death fatwa for Salman Rushdie on February 14, 1989. British Government defended Rushdie's stand and writing in the name of freedom of expression. ${ }^{1}$ European Union and USA came forward to support Rushdie in name of freedom of thought and expression. In 2007 writer Rushdie was honoured with Knight Award by British Queen.

French weekly cartoon magazine Charlie Hebdo published caricature of our Prophet (sm) and depicted Him as the leader of Muslim terrorist in 2011. On January 7, 2015 home grown terrorists attacked the Head Office of Charlie Hebdo, weekly newspaper killing 14 people. Immediately after such attack Western Governments viz., USA, UK, Germany, Australia, EU portrayed this magazine the upholder and icon of freedom of speech, press, values of human dignity. Not only that they symbolized Charlie Hebdo the safeguard of free society. ${ }^{2}$

In Bangladesh left political parties, the leaders, and their disciples, and a small section of educated class as well as cultural activists practice and preach western style life such as free-mixing, taking wine, wearing short dresses. This section does not follow and practice Bangladeshi social and moral norms and values. A section of the class writes anti-Islamic comment in books, face books, web-sites, smearing our Prophet Mohammad (sm) and pious Muslims. Interesting thing is that these people follow religion. Two members-Ahmed Rajib Haider and Abhijit Roy of this class were murdered on February 15, 2013 and on February 22, 2015 respectively. Western governments in reaction to these killings said that such incidents were a threat to the democracy and secularized politics in Bangladesh. Most of the news papers excepting two or three in Bangladesh reiterate the same view in their circulations. This behavior of western governments particularly USA, UK and EU are not just and sound, nor match with secularism. It may be their double standard or be the dark reality of their culture. Secularized culture does not mean dual role, deception, undue benefit and abusive use of freedom and free society. It is rational and the practice of reason which nourish values of human society for betterment of mankind. In this context the practice of abnormal sex ties i.e, lesbian marriage and gay marriage in the name of human rights are against the secularized culture because such type of bond or practice is a threat to the very existence of human society. Secularism is the combination of universally acceptable norms and values of morality and ethics emanating from the rationality and positive reason of human being. Thus as a naturalist if one imbibes the law of nature- practice of nudity in the social order will not fall within the term of secular culture.

Therefore practice of religion is a must for the learning of morality, ethics, just and unjust. Learning process begins in family or in other words at home. If a family does not practice and nourish moral and ethical norms and values, children of that family will never be secular in dealing with society and state affairs. Democracy and rule of law is a utopia in that society.

\section{Conclusion:}

Rule of law is not a commodity easily procurable in each and every political society. Democratic polity assists in the creation of basic elements of rule of law. Democracy and rule of law cannot attain its goal unless the government and the governed nourish and practice secularized culture in their thinking, behavior, policy and action. Being a member of authoritarian system proclamation of rule of law is merely an imagination. Again in the motherlands of democracy assertion on the part of both the treasury bench and the opposition for complete realization of rule of law becomes farce when personality integration and reasons are not found in their actions and government policies. Form of government does not matter at all if society as a whole is guided by secularized culture and government is run on the dictate of right reason. Living on the peak of garbage of dead moral and ethical values exploration of rule of law is impossible. However if family imbibes and teaches its members morality and secularized culture the dream of Dicey may have a chance to get explored in the world.

\section{Reference:}

Almond Gabriel A.\& Jr. G. Bingham Powell, Comparative Politics A Developmental Approach, Little Brown \& Company, Boston, USA, 1966, Almond Gabriel A. \& Verba Sidney, The Civic Culture, Princeton University Press, New Jersey, 1972 Jennings Sir Ivor, Cabinet Government, Cambridge University Press, UK, 1969

MacIver R.M., The Web of Government, Macmillan Company, New York, 1961

Macridis C. Roy \&Brown E. Bernard, Comparative Politics Notes and Readings (edited), The Dorsey Press, Homewood, Illinois, 1964

\footnotetext{
${ }^{1}$ The Guardian, February 15, 1989

${ }^{2}$ The Telegraph, January 8 and 12, 2015.
} 
Pye Lucian W. \& Verba Sidney, Political Culture and Political Development (Edited), Princeton University Press, New Jersey, 1965

Shils Edward, Political Development in the New States, Mouton \& Co., The Hague-Paris, 1966

U.S. Senator John McCain, Senator Kelly Ayotte, Senator Richard Burr and Senator Lindsey Graham hold a news conference to talk about new legislation to restrict prisoner transfers from the detention center at Guantanamo Bay, at the U.S. Capitol in Washington January 13, 2015.

Entelis, John P., Democracy Denied: America's Authoritarian Approach Towards the Maghreb - Causes \& Consequences, XVIIIth World Congress of the International Political Science Association, Quebec, 1-5 August 2000 .

5 dictators the U.S. still supports". The Week. Retrieved 2014-08-10

DeConde, Alexander et al., ed. (2001). "Dictatorships". Encyclopedia of American Foreign Policy, Volume 1. Simon \& Schuster. p. 499. ISBN 9780684806570.

Melissa Anders 1 manders@mlive.com Fellow on Twitter- On April 21, 2014.

The Ministry of Law, Justice and Parliamentary Affair (1975), The Fourth Constitutional (Amendment) Act, Dhaka

\section{Print Media}

The Ajker Kagoj (2015), August 16, p.1, Dhaka

The Bangladesh Observer (1975), August 21, p.1, Dhaka

The Bangladesh Observer (1977), June 1, p.1, Dhaka

The Janakantho (2015), August 16, p.1, Dhaka

The Bangladesh Pratidin (2015), August 16, p.1, Dhaka

The Daily Star (2015), August 31, p.1, Dhaka

The Daily Star (2015), January 29, p.1, Dhaka

The Daily Star (1990), December 7, p.1, Dhaka

The Daily Star (2013), July 4, p.1

The Independent (1996), June 14, p.1, Dhaka

The Ittefaq (1977), June 1, p.1, Dhaka

The Morning News (1975), August 20, p.1, Dhaka

The Naya Diganta (2015), February 27, p.1, Dhaka

The New Age (2014), November 13, p.1, Dhaka

The New Nation (1996), February 13, p.1, Dhaka

The Prothom Alo (2015), January 29, p.1, Dhaka

The Prothom Alo (2015), August 11, p.1, Dhaka

The Guardian (1989), February 15, p.1

The guardian (2010), Wednesday, November 10

International Business Times (2015), Friday, February 6

Reuters, UK Edition (2015), Monday, January 19

The Telegraph (2015), January 8 and 12, p.1

\section{Electronic Media}

BTV News (2015), January 28, Dhaka

Bd News.com (2015), January 28, Dhaka

Rtv News (2014), January 5, Dhaka

Banglavision TV News (2014), January 5, Dhaka

ETV News (2014), January 5, Dhaka

Channel 24 (2014), January 5, Dhaka

$B B C$ News (2001), at 8 pm, October 6, London

$B B C$ News (2014), September 22, London

(Law after st Thomas Acquinas)

http://sixthformlaw.info/01_modules/other_material/law and morality/0 what is law.htm 